\title{
ELEMENTOS PARA UNA HISTORIA DEL PRESERVATIVO EN LA ESPAÑA CONTEMPORÁNEA
}

por

\author{
JEAN-LOUIS GUEREÑA \\ CIREMIA, Universidad François Rabelais, Tours
}

RESUMEN: En el siglo XIX y en la primera mitad del XX, salvo sin duda durante la Segunda República, la norma en las relaciones sexuales, impuesta por la Iglesia católica, ba sido la probibición de cualquier método o técnica que no fuera "natural». La utilización del preservativo masculino o condón no escapó pues a la regla. Desde luego, cumplia dos funciones: controlar la fecundidad y precaverse de enfermedades de transmisión sexual (en el trato con prostitutas esencialmente). Tras examinar la introducción de la palabra y de la realidad desde fines del siglo XVIII, se estudiará el discurso médico en el siglo XIX y a principios del XX, a menudo opuesto a la utilización del condón como preservativo frente a las enfermedades venéreas. Sin embargo, las publicidades aparecidas en la prensa, desde principios del siglo XX, y la existencia de varias casas especializadas con sus correspondientes catálogos, demuestran una utilización popular de los preservativos en las prácticas sexuales de los. españoles, tanto como protección antivenérea que como medio anticonceptivo.

Palabras Clave: Sexualidad. Preservativos. Enfermedades venéreas. Medios anticonceptivos. España. Siglos XIX y XX.

\begin{abstract}
In the nineteenth and early twentieth centuries, except during the Second Republic, the rule imposed by the Catbolic Church in sexual relations was the probibition of any «unnatural» method or technique. The use of a masculine preservative or condom was no exception to this rule. The condom fulfilled two functions: control of fertility and prevention of sexually transmitted disease (particularly in treatises on prostitution). We examine bere the introduction of both the term and its referent toward the end of the eighteenth century, and look at medical discourse in the nineteenth century, often opposed to the use of a condom as protection against venereal disease. However, advertisements in the press, beginning in the twentieth century, and the existence of specialized companies with their corresponding catalogs, show that preservatives were popular in Spanish sexual practices, both for anti-venereal protection and as a contraceptive device.
\end{abstract}

KEY WORDS: Sexuality. Preservatives. Venereal disease. Contraceptive devices. Spain, $19^{\text {th }}$ and $20^{\text {th }}$ century. 
Las políticas anticonceptivas ya han sido un tanto estudiadas en el caso español ${ }^{1}$, pero poco se sabe históricamente de las prácticas anticonceptivas concretas utilizadas por las parejas españolas, legales o no, en la época contemporánea hasta la aparición de la píldora anticonceptiva, como el coitus interruptus, condenado repetidas veces por la Iglesia católica — que defendía por su parte la continencia- y a menudo calificado de «onanismo conyugal» ${ }^{2}$, o la lactancia prolongada.

Nos centraremos aquí en el preservativo masculino utilizado tanto como profiláctico venéreo o instrumento anticonceptivo, sin duda el más fácil de uso y el relativamente de mayor eficacia, pese a las condenas o los prejuicios médicos. El tema no es nada fácil desde luego y nos contentaremos aquí de meros apuntes sobre el tema, basándonos en los documentos que hemos podido hallar, en una forma de rastreo arqueológico, y en los estudios que han podido realizarse para otros países ${ }^{3}$.

En su trabajo pionero publicado en 1971, el hispanista francés Pierre Conard, tras observar que en medios urbanos a principios del siglo XX «la voluntad de limitación del número de nacimientos parece reforzarse», a pesar de su fracaso aparente (aumento del número de hijos por pareja), señala que «ningún indicio permite pensar que el preservativo masculino haya conocido una real difusión antes de la Primera Guerra mundial, ni incluso como protección contra las enfermedades venéreas tan preocupantes en la época» ${ }^{4}$.

Salvo durante la Segunda República, la norma, impuesta por la Iglesia católica, ha sido la prohibición de cualquier método o técnica que no fuera «natural». La utilizaçión del preservativo masculino o condón no escapó a la regla y

1 Álvarez Peláez, Raquel: «La mujer española y el control de natalidad en los comienzos del siglo XX», Asclepio (Madrid), vol. XLII-2 (1990), pp. 175-200; NASH, Mary: «El neomalthusianismo anarquista y los conocimientos populares sobre el control de la natalidad en España», en NASH, Mary (Ed.): Presencia y protagonismo. Aspectos de la bistoria de la mujer, Barcelona, Ediciones del Serbal, 1984, pp. 307-340.

2 ARCENIEGA, Manuel de: Metodo practico de hacer fructuosamente confesion general de muchos años, util para confesores, y penitentes por quanto se proponen, y resuelven los casos mas frequentes que llegan al confesonario. Explicase tambien lo que el christiano debe saber, conforme a las instrucciones que nos da el santo concilio de Trento, su celebre catecismo y el de Amato Pouget, Tercera impresion, Madrid, En la Imprenta de Ramon Ruiz, 1794, pp. 446-449 («De los pecados de los casados»); KNOCH, A.: El onanismo conyugal y el Tribunal de la Penitencia, Traducido de la $4^{a}$ edición francesa por el Rdo. Dr. D. Francisco de P. RIBAS Y SERVET, Pbro., Barcelona, Tipografía Católica, 1914, 103 p. Ver Flandrin, Jean-Louis: L'Église et le contrôle des naissances, Paris, Flammarion (Questions d'histoire, 23), 1970, 139 p.

3 GAMSON, Joshua: «Rubber Wars: Struggles over the Condom in the United States», Journal of the History of Sexuality (Chicago), vol. 1 (1990), $\mathrm{n}^{\circ}$ 1, pp. 262-282, y TRUMBACH, Randolph: «The Condom in Modern and Postmodern Culture», Ibid., vol. 2 (1991), $\mathrm{n}^{\circ} 1$, pp. 95-98. Existe en castellano una muy somera visión general por SÁNCHEZ-GóMEZ, Rodrigo: Historia del preservativo, Madrid, Ediciones Cúbicas, 1988, 59 p.

4 CONARD, Pierre: «Sexualité et anticléricalisme (Madrid, 1910)», Hispania (Madrid), t. XXXI, n 117 (Enero-Abril de 1971), p. 117.

Hispania, LXIV/3, núm. 218 (2004) 869-896 
fue condenada, en particular, por el Vaticano en 1826, en fecha relativamente temprana pues, por trastornar «los decretos de la providencia, que ha querido castigar a sus criaturas por donde ellas habían pecado" 5 .

Desde luego, el preservativo cumplía dos funciones, controlar la fecundidad y precaverse de enfermedades de transmisión sexual ante coitum (en el trato con prostitutas esencialmente), como lo reconoce la Enciclopedia Espasa en 1912, no sin reservas morales, en su definición del condón:

«Saquito de tripa o de goma que se usa como preservativo de las enfermedades venéreas y sifilíticas. Su destino primitivo era el fraude en las relaciones sexuales para impedir la procreación $[\ldots] \gg{ }^{\circ}$.

El preservatismo masculino viene conocido pues esencialmente en castellano bajo la denominación de "condón» que examinaremos más abajo, pero el escritor Camilo José Cela [1916-2002] ha podido apuntar en el tomo segundo de su Diccionario secreto las siguientes voces afines, más o menos utilizadas desde luego: aparejo profiláctico, calcetín, calcetín de viaje, capote, capote inglés, chumpa, disfraz, forro, funda, goma, goma higiénica, goma profiláctica, gomita, gorro, impermeable, impermeable inglés, jebe, látex, margarita, objeto de goma, paracaídas, paraguas, poncho, sombrero, tripajo, velo rosado 7 .

En Europa, se conoce al menos desde el siglo XVI en su uso profiláctico, cuando en 1564 el anatomista italiano Gabriel Fallopio [1523-1562] describe en su publicación póstuma De Morbo Gallico el uso de un fino tejido de lino para envolver el órgano masculino durante el acto sexual previniendo de este modo las enfermedades venéreas. Los primeros preservativos utilizados en Europa en el siglo XVII eran pues de lino o de seda, de uso incómodo y poco seguro, y en el siglo XVIII aparecieron condones de cuero, «hechos de tripa de ganado lanar u otros animales» ${ }^{8}$, a partir del intestino ciego (caecum) del animal.

A finales del siglo XIX, ya se empezaron a utilizar en Europa preservativos de caucho, fabricados en los Estados Unidos a partir de 1850 tras el descubrimiento de la vulcanización en 1840 por Charles Goodyear [1800-1860], contribuyendo a su difusión masiva por el abaratamiento del coste del producto y a su mayor seguridad y comodidad de uso. En 1870, el inglés Mac Intosh, especializado en la fabricación de impermeables, empieza a producir industrialmente preservativos de caucho, exportando hacia toda Europa, incluida España.

5 S. E. y M. [ESCOLAR Y MORALES, Serapio]: «Medios profilácticos para precaver las enfermedades venéreas», Boletín de Medicina, Cirugía y Farmacia. Periódico oficial de la Sociedad Médica General de Socorros Mutuos (Madrid), t. IV (1837), p. 62.

6 Enciclopedia ilustrada bispano-americana, Barcelona, Espasa Calpe, t. XIV, 1912, p. 1101.

7 Cela, Camilo José: Diccionario secreto. Tomo II Series Pis y afines, Madrid-Barcelona, Alfaguara (Hombres, hechos e ideas), 1971, p. 622.

8 Cela, Camilo José: Enciclopedia del erotismo, Barcelona, Sedmay Ediciones, 1976, t. I, p. 112 [voz «anticonceptivo»]. 


\section{EL CONDÓN. INTRODUCCIÓN DE LA PALABRA Y DE LA REALIDAD}

La palabra castellana «condón» — «funda preservativa de la pija; se utiliza durante el coito en evitación de la fecundación de la mujer o del contagio venéreo", según la definición facilitada por Camilo José Cela ${ }^{9}$ - procedería del nombre de un supuesto médico inglés Dr. Condom, según una errónea afirmación, ampliamente repetida, divulgada a principios del siglo XIX por el médico, de origen austriaco pero naturalizado francés, Franz Xaver Swediaur [1748$1824\}^{10}$, pero resulta ser más bien una deformación fónica del latín «condum», acusativo del sustantivo "condus», formado sobre el verbo "condere», que significa en una de sus acepciones esconder y por lo tanto proteger ${ }^{11}$. No parece tener fundamento, por otra parte, la referencia a la ciudad francesa de Condom, en el centro del Gers, y a la invención del condón por carniceros del matadero local. Otra etimología avanzada sería la del nombre del coronel inglés Cundum, al servicio del Rey Carlos II, y supuesto inventor hacia 1665 de este preservativo.

También utilizada en inglés (cundum y sobre todo condom) desde la segunda mitad del siglo XVII ${ }^{12}$, y en francés (condon o condom) desde principios del siglo $\mathrm{XVIII}^{13}$, la voz "condón» aparece en el léxico castellano en la segunda mitad del siglo XVIII. La menciona, en particular, Nicolás Fernández de Moratín [1737-1780] en su célebre poema titulado Arte de las putas, compuesto hacia 1772. Aunque la primera edición conocida apareciera sólo a finales del siglo XIX, verosímilmente a cargo de Emilio Cotarelo y Mori [1857-1935], en una corta tirada de 50 ejemplares a partir de una versión manuscrita de 1813 «hecha por un extranjero» ${ }^{14}$, varias copias manuscritas del texto moratiniano

9 Cela, Camilo José: Diccionario secreto. Tomo II Series Pis y afines, op. cit., p. 617. Por su parte; el lexicógrafo Julio Casares apunta sólo su función de preservativo antivenéreo: «Funda de goma elástica que se usa en el acto venéreo para evitar el contagio de ciertas enfermedades» (CASARES, Julio: Diccionario ideológico de la lengua española, Barcelona, Editorial Gustavo Gili, S.A., 1948, p. 264, y $2^{\text {a }}$ ed., 1959, p. 207).

10 Swediaur F.: Traité complet sur les symtômes, les effets, la nature et le traitement des maladies sypbilitiques, $7^{\mathrm{a}}$ ed., Paris, Méquignon, 1817, t. I, p. 167.

11 Gaffiot, Félix: Dictionnaire illustré Latin Français, Paris, Librairie Hachette, 1934, p. 380.

12 Rochester, Roscommon y Dorset: Panegyric upon Cundum, 1667, cit. por PARTRIDGe, Eric: Dictionary of slang, London, 1937; TURNER, Daniel: Practical dissertation on the veneral disease, London, 1717, p. 197, cit. por GuILLEMAIN, Ch.: Contribution à lHistoire des Préservatifs contre les dangers vénériens. Le condom ou capote anglaise, Separata del Album du Crocodile, Lyon, Mayo-Junio de 1953, p. 8.

13 El diccionario francés Robert menciona la fecha de 1708 para la voz «condon»'y de 1717 para «condom (REY, Alain (Dir.): Le Grand Robert de la langue française: dictionnaire alphabétique et analogique de la langue française, Paris, Le Robert, $2^{\mathrm{a}}$ ed., 1985, t. 2). Ver ASTRUC, Jean: De morbis veneris libri sex, $3^{\mathrm{a}}$ ed. (en francés), 1755 [1 $1^{\mathrm{a}}$ ed. en latín, 1736], t. III, pp. 115-116, cit. por GUILlemain, Ch.: Contribution à l'Histoire des Préservatifs contre les dangers vénériens, op. cit., p. 8.

${ }_{14}$ Arte de las putas. Poema. Lo escribió Nicolás Fernández de Moratín. Abora por primera vez impreso, Madrid, s.i., 1898, 95 p. Se trata de la primera edición conocida, aunque existiría una primera hacia 1830 (Album de Venus, seguido del Arte de Putear de Moratín, s.l., s.i., s.f. [c. 1830], 64-102 p., con 
circulaban clandestinamente antes (y después) de $1777^{15}$, fecha en la que fue prohibido por edicto inquisitorial del 20 de junio de 1777, incluyéndose posteriormente en el Índice último de los libros probibidos de 1790, así como en carteles impresos para ser colocados en iglesias y lugares públicos ${ }^{16}$ :

«Tu así del Soto a casa ve a atacarte;

mas yo quiero del todo asegurarte

facilitando del condón el uso.

Feliz principio a esta artimaña puso

de un fraile la inventiva, que de un fraile

sólo, o del diablo ser invención pudo.

[...] El condón de este modo fue inventado,

Después los sutilísimos ingleses,

filósofos del siglo, le han pulido,

y a membrana sutil le han reducido,

que las almendras le conservan fresco

con el aceite que destilan dulce;

y las putas de Londres son multadas

si no ofrecen bandejas de condones,

que les hacen venir desde la China.

$\mathrm{Y}$ en Montpellier se venden a paquetes,

y en las tiendas de Pérez y Geniani,

si los pagares bien y con secreto,

y por los Secretarios de Embajada, que a la nuestra remiten las naciones.

[...] Mas sólo con andar toda la villa encontrarás remedio en los portales desarrugando un poco tu rezmilla.

Supongo que continuo armado sales

«finas láminas»), cit. por RodríGuez MoÑINO, Antonio: Relieves de erudición (del Amadís a Goya). Estudios literarios y bibliográficos, Valencia, Castalia, 1955, p. 123, n. 59, y PALAU Y DULCET, Antonio: Manual del librero bispanoamericano (...), Barcelona, Librería Palau, t. V, 1951, p. 334, $\mathrm{n}^{\circ}$ 89.413 (comentario a la ed. de 1898).

15 Arte de las putas, op. cit., 1898, pp. 7-8 («un bibliófilo muy inteligente nos manifestó tener un vago recuerdo de haber visto otro manuscrito fecha [sic] en 1772»). Según Isabel Colón Calderón y Gaspar Garrote Bernal, el poema de Moratín debió de componerse en torno a 1772 (FERNÁNDEZ DE MORATÍn, Nicolás: Arte de putear, Edición, introducción, notas y glosario de COlÓN CALDERÓN, Isabel y GARROTE BERNAL, Gaspar; Archidona, Ediciones Aljibe (Erótica Hispánica, 1), 1995, pp. 13-16). Ver FoulchÉ Delbosc, R.: «Los vicios de Madrid (1807)», Revue Hispanique (Paris-New York), t. XIII (1905), p. 180.

16 Archivo Histórico Nacional, Madrid, Inquisición, leg. 4428-30, fol. 3va ; Índice último de los libros probibidos y mandados expurgar para todos los Reynos y Señorios del Católico Rey de las Españas el Señor Don Carlos IV. Contiene en resumen todos los libros puestos en el indice expurgatorio del año 1747, y en los Edictos posteriores hasta fin de Diciembre de 1789, Madrid, En la Imprenta de Don Antonio de Sancha, 1790, p. 16.; FERNÁNDEZ NIETO, Manuel: Introducción a su edición de FERNÁNDEZ DE MORATín, Nicolás: Arte de las putas, Madrid, Ediciones Sirio (Biblioteca clásica de autores festivos), 1977, pp. 14-15.

Hispania, LXIV/3, núm. 218 (2004) 869-896 
del condón, tu perenne compañero, y así no ensuciarás los hospitales»17.

La utilización del condón viene asociada prioritariamente pues desde entonces al trato sexual con prostitutas y a la prevención de las enfermedades venéreas. Cabe precisar que el manuscrito de 1804 utilizado para la edición de Isabel Colón Calderón y Gaspar Garrote Bernal, procedente de la colección de Antonio Rodríguez Moñino y María Brey, indica "gondón» y «gondones», que hemos rectificado por «condón» y "condones», según lo publicado en la edición de $1898^{18}$. Sin embargo, la voz «gondon» también viene registrada en francés ${ }^{19}$.

El origen inglés del preservativo (no por nada se conoce en francés por «capote anglaise» cuando los ingleses devuelven la cortesía calificándolo de "french letter»), o al menos la decisiva contribución inglesa al perfeccionamiento y a la difusión del mismo en la Europa del siglo XVIII ${ }^{20}$, incluida España, viene confirmado por una publicidad de la casa inglesa Philips, del siglo XVIII, que afirma seguir «in its original flate of reputation», y en donde «all gentlemen of intrigue may be supplied with those Bladder Policies, or implements of safety, which infallibly secure the health of our costumers, superior in quality as has been demonstrated in comparing samples of others that pretend the name of Philips", asegurando contar entonces con gran pedidos de Francia, España, Portugal, Italia, y otros lugares extranjeros ${ }^{21}$. Por otra parte, un grabado inglés de 1744 que acompaña la publicación de un poema anónimo titulado The Machine or Love's Preservative representa concretamente la fabricación artesanal y el control de preservativos en un local londinense ${ }^{22}$.

Según otro documento, en Utrecht (Países Bajos), y en tiempos de la celebración del tratado que ponía fin a la guerra de sucesión a la corona española (o sea en 1713), un comercio local ya fabricaba «certaines coiffes ou vessies très fines, qu'on applique à l'instrument du plaisir, et qui plus efficaces que si elles

17 Fernández de MORATín, Nicolás: Arte de putear, op. cit., 1995, pp. 149 (canto II, v. 139144), 151 (v. 206-217) y 156 (v. 369-374).

${ }_{18}$ Arte de las putas, op. cit., 1898, pp. 44-45, 47 y 53

19 Gulllemain, Ch.: Contribution à l'Histoire des Préservatifs contre les dangers vénériens, op. cit., pp. 9 y 16.

${ }^{20}$ Himes, Norman E.: A Medical History of Contraception, 'Baltimore-London, Williams and Wilkins, 1936, pp. 188-200; SAUVY, Alfred, BERGUES, Hélène y RIQUET, M.: Historia del control de nacimientos, Barcelona, Península, 1972, pp. 122 y 138; McLAREN, Angus: Histoire de la contraception de ['Antiquité à nos jours, Prefacio del Doctor Pierre SimON, Paris, Noêsis, 1996 [ed. inglesa, 1990 y ed. española, 1993], p. 241.

${ }^{21}$ Prospecto de la Casa Philips (s.f., pero del siglo XVIII) reproducido por VIDAL, Vincent: La petite bistoire du préservatif, Paris, Syros, 1993, p. 21.

22 The Machine or Love's Preservative. A Poem in Imitation of Homer and Virgil, and Dryden and Pope, London, T. Reynolds, 1744, cit. por GuIllemain, Ch.: Contribution à l'Histoire des Préservatifs contre les dangers vénériens, op. cit., p. 15, y por VIDAL, Vincent: La petite histoire du préservatif, op. cit., pp. 20-21 (con reproducción del grabado).

Hispania, LXIV/3, núm. 218 (2004) 869-896 
étaient de fer, le mettent en état d'aller braver le péril dans le fort même où il se cache», mandando sus productos a diversos países extranjeros ${ }^{23}$.

Se conservan en colecciones privadas y museos algunos preservativos de la época o algo más tarde como el que se subastó en Londres por Christie's en $1992^{24}$. De principios del siglo XIX, tal ejemplar histórico, de origen francés, mide unos veinte centímetros y está fabricado a partir de una tripa animal. Un galón de seda en su apertura le permite quedar mantenido alrededor del pene. Se puede observar además la presencia de una escena erótica representando a una religiosa semi-desnuda designando con la mano a su futuro amante entre tres eclesiásticos en erección y anunciando: «Éste es mi elegido» ("Voilà mon choix»).

A finales del siglo XIX, seguían utilizándose preservativos del mismo tipo, en cuanto a la forma y a la textura, fabricados a menudo en tripa de carnero, y por lo tanto poco confortables ${ }^{25}$. Lavados, podían servir en varias ocasiones. Pero su precio relativamente alto y su estrecha relación con las enfermedades venéreas limitaban entonces su uso fuera de los medios vinculados a la prostitución.

Junto con el espectáculo de la prostitución callejera a fines del siglo XVIII y a principios del siglo XIX, la propagación de las enfermedades venéreas constituía desde luego un claro motivo de preocupación. Índice del temor popular creciente ante el desarrollo de las enfermedades de transmisión sexual lo constituía, por ejemplo, la multiplicación de «papelotes indecentes que por desgracia se notan en todas las esquinas, anunciando secretos y personas de habilidades raras para curar las enfermedades venéreas», señalada por Bartolomé Colomar en una nota a su traducción del tratado sobre enfermedades venéreas de $\mathrm{F}$. Swediaur publicada en $1808^{26}$.

Y, aunque constantemente denunciado y perseguido por autoridades policiales y religiosas, como en los demás países católicos desde luego, el uso del preservativo masculino o condón parece pues haberse introducido entonces en España de modo clandestino, seguramente por importación en contrabando de Inglaterra y sobre todo de Francia (donde la Casa del «Gros Millan», establecida en la plaza del Palacio Real, gran centro de la prostitución parisiense, fabricaba preservativos desde 1780 , según reza su publicidad ${ }^{27}$ ).

${ }^{23}$ FRESCHOT, Casimir: Histoire amoureuse et badine du Congrès et de la Ville d'Utrecht, Liège, Chez Jacob le Doux, s.f. [c. 1714], pp. 167-172, cit. por GulllemaIn, Ch.: Contribution à l'Histoire des Préservatifs contre les dangers vénériens, op. cit., pp. 42-44.

24 VIDAL, Vincent: La petite histoire du préservatif, op. cit., pp. 28-29 (con ilustración). Ver también p. 26.

${ }^{25}$ Ibid., p. 19 (con ilustración).

${ }^{26}$ F. SWEDIAUR, Tratado completo de los síntomas, efectos, naturaleza y verdadero método de curación de las enfermedades venéreas, Traducido de la quinta y última edición francesa, con notas y adiciones, por Don Bartolomé Colomar, Médico de número de los Reales Ejércitos, y de los Hospitales General y Pasión de esta Corte, e individuo de la Real Academia Médica de Madrid \&, Madrid, En la Imprenta de Repullés, vol. III, 1808, p. 76.

${ }_{27}$ Gulluemain, Ch.: Contribution à lHistoire des Préservatifs contre les dangers vénériens, op. cit., $\mathrm{p}$. 20 (con ilustración). 
Un decreto de 1803, verosímilmente un edicto inquisitorial del mes de ju$\operatorname{lio}^{28}$, cuyo original no hemos visto, prohibe a principios del siglo XIX los «tendones que sirven para impedir la propagación humana, siendo invención de la herejía, fomento de libertinaje y escándalo de la naturaleza»:

"Queda muy prohibido como contrabando por el Gobierno y no se escapará de la justicia ni del tribunal de la Inquisición»29.

Podemos pensar razonablemente, por otra parte, que los soldados franceses - y más aún sus oficiales - contribuyeron a la introducción del preservativo en el periodo de la Guerra de la Independencia, que significó muy seguramente un periodo de recrudecimiento de las enfermedades de transmisión sexual que nos es difícil medir ${ }^{30}$, debido en particular al «relajamiento» de las costumbres del que podría testimoniar el número de amancebamientos y de expósitos, al crecimiento de la prostitución por razones esencialmente económicas y de supervivencia, y a la ausencia de medidas sanitarias adecuadas en un país entonces duramente asolado por los «desastres de la guerra» ${ }^{31}$. Sin embargo, en las diecinueve medidas articuladas en 1809 por el médico militar Antonio Cibat [1771-1811] "para contener los progresos de la sífilis», sólo se apuntaba que «la limpieza y aseo son unos preservativos excelentes de los contagios» ${ }^{32}$, y en nada se aludía al condón.

En la documentación del Archivo del Episcopado de Barcelona, Joan Bada ha podido encontrar sin embargo varias referencias concretas a la posesión y venta de preservativos masculinos en la Barcelona fernandina, lo que no era entonces sin peligro ${ }^{33}$. En 1815, se autodenuncian - no sabemos por qué razones - como vendedores de preservativos Joan Farrerons y Teresa Corominas,

${ }_{28}$ Ver Domergue, Lucienne: La censure des livres en Espagne à la fin de l'Ancien Régime, Madrid, Casa de Velázquez (Bibliothèque de la Casa de Velázquez, 13), 1996, p. 213.

29 Decreto de 1803, cit. sin indicar fecha exacta ni referencia por ROGLAN, Joaquim: La Barcelona eròtica, Barcelona, Angle Editorial (Catalunya en blanc i negre III), 2003, p. 20. No hemos encontrado dicho decreto ni en la Novísima Recopilación ni en la Colección de Reales Decretos del Archivo Histórico Nacional ni en el Prontuario de GarRIGA, José: Continuación y Suplemento del Prontuario de D. Severo Aguirre, que comprehende las cédulas, resoluciones, Ec. expedidas el año de 1803, y algunas de las anteriores, Madrid, Imprenta de Don Ramón Ruiz, 1804, XVI-287 p.

30 Ver sobre el conocimiento de estas enfermedades en aquel entonces el balance de D. A. B. [Ballano, Antonio]: Diccionario de Medicina y Cirugía, o Biblioteca manual médico-quirúrgica, $2^{\mathrm{a}}$ ed., $\mathrm{t}$. $7^{\circ}$, Madrid, Don Francisco Dávila, 1817, art. «VenÉREAS (enfermedades)», pp. 317-344.

31 GUEREÑA, Jean-Louis: La prostitución en la España contemporánea, Madrid, Marcial Pons Historia, 2003, pp. 36-37.

32 CIBAT, Antonio: «Medidas propuestas por $\mathrm{D}$. Antonio Cibat para contener los progresos de la sífilis" (Madrid, 24-X-1809), El Siglo Médico, Madrid, vol. 8, nº 379, 7-IV-1861, p. 222 (medida $\left.17^{a}\right)$. Ver GUereÑA, Jean-Louis: La prostitución en la España contemporánea, op. cit., pp. 45-57.

33 BADA, Joan: L'església de Barcelona en la crisi de l'antic règim (1808-1833), Barcelona, Facultat de Teologia de Barcelona-Editorial Herder (Col.lectània Sant Pacià $n^{\circ}$ XXXV), 1986, p. 329.

Hispania, LXIV/3, núm. 218 (2004) 869-896 
lo que indica que ya por estas fechas, al salir de la Guerra de la Independencia, existe un mercado de preservativos con sus intermediarios ${ }^{34}$. En 1820, son embargadas en la Fontana de Oro «unas piezas de tripa a propósito para condones». El posesor de las mismas era de origen francés, lo que justifica la intervención del Consulado de su país, pero la partida había desaparecido en el momento de proceder a embargarla ${ }^{35}$. Y, en 1827, el caso de Maria Crusellas, en poder de la cual se habían encontrado veinticuatro preservativos, es presentado al tribunal eclesiástico, el cual, de acuerdo con la Real orden de 1816, se inhibe y lo devuelve a la Audiencia ${ }^{36}$.

Un curioso documento, de cuya autenticidad no estamos seguros y procedente supuestamente de la Dirección General de Rentas y Aduanas, con fecha de noviembre de 1824 , da a pensar que la palabra no se había aún popularizado del todo o que por lo menos no se había introducido en el léxico administrativo de la época. Verdad es que se trataba de la segunda monarquía absolutista de Fernando VII, la «ominosa década». En este documento, Francisco López de Alcaráz, Director general de Rentas y Aduanas, contesta al oficio del Secretario de Estado y del Despacho de Hacienda preguntando «qué es condón», facilitando de paso una etimología italiana y una fabricación a partir de algunos pescados:

«Esta palabra condón, es de origen italiano y término provincial de uno de los departamentos litorales del reino de Nápoles, que vale tanto como bolsa. Consiste en una membrana muy sutil que forma el buche de cierto pescado que se cría en las costas del mar Adriático, preparada a la manera de las vitelas para diferentes usos. [...] Los meditativos ingleses, fecundos en recursos de todas clases, al observar el estrago que el mal venéreo hacía en las tripulaciones de sus buques y tropas destinadas a las posesiones o expediciones ultramarinas, hallaron el preservativo del acceso del virus al conductor natural, revistiéndolo cón dicha membrana o tripas de algunos pescados y animales delicados, y [...] además tiene ya por objeto desahogar la lubricidad, sin riesgo de generaciones [...] ${ }^{37}$.

Aún en 1836, desde Londres, donde escribe sus inéditos Recuerdos de mi vida, José Izquierdo Guerrero de Torres siente la necesidad de explicitar ampliamente el "Modo de hacer los condones», como si fuera algo nuevo para él, ofreciéndonos una precisa descripción (junto con un dibujo) de su fabricación ya relativamente industrializada y sofisticada, y corroborando de paso el papel inglés en la materia:

${ }^{34}$ Archivo del Episcopado de Barcelona-Avellà Correspondencia de oficio I, fol. 122, Barcelona, 14 dicembre de 1815, Avellà-Felipe Martín de Igual.

35 Ibid., I, fol. 301, Barcelona, 26 enero de 1820, Avellà-Cónsul de Francia.

${ }^{36}$ Ibid., II, c. 1030, Barcelona, 8 febrero de 1827, Avellà-Gobernador de la Real Sala del Crimen.

37 «Informe de la Dirección general de Rentas Aduanas, acerca de la R.O. de 18 de Noviembre de 1824, expedida por el Departamento de Hacienda, preguntando 'qué es condón'«, en Floresta poética de varios autores, Madrid, 1901, $3^{\mathrm{a}}$ serie, pp. 13-15, cit. por Cela, Camilo José: Enciclopedia del erotismo, op. cit., t. I, pp. 108-109, y Diccionario secreto. Tomo II Series Pis y afines, op. cit., pp. 619-620.

Hispania, LXIV/3, núm. 218 (2004) 869-896 
«Se mandan hacer moldes de madera [...] que sean de tres tamaños, y un

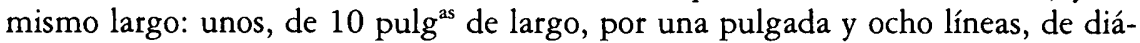
metro, en la base; otros de 1 y 10 , y otros de dos pulgadas: haciéndoles a todos un bujerito [sic] en el centro de su base, de 3 o 4 pulgadas de profundidad para fijarlos en una mesa, $\&^{\mathrm{a}}$ cuando se trabaja con ellos.

Los condones se hacen de una piel que solamente se saca de la entre-tela interior de la tripa que no tiene salida (única que tienen todas las reses vacunas, donde se deposita la inmundicia que comúnmente creo que llaman El Morcón [...]. De estas luego que están bien limpias, 'se les quita la tela interior, que es la que sirve (cuyas operaciones todas las hacen los Matachines; quedándose con la tripa exterior que sirve para otras cosas [...].

El modo de hacer los condones es el siguiente: se corta la piel [...] a lo ancho, teniéndose siempre los pedazos en agua, y tomando sólo los que se necesitan. Dichas piezas se ponen sobre el molde, cuidando que vayan muy estiradas, y con unas pinzas se estiran los bordes, de modo que no se conozcan quedando casi imperceptible[mente] unidos con la madera; quitando con la mayor delicadeza (sin estropear el molde) con un cortaplumas cualquier borde grueso que haya; añadiendo al instante las piezas, antes que nada se seque, poniéndolos con igualdad, y cuidado, dejando una porción suficiente sobre el borde de las otras, las cuales en estando secas, quedan naturalmente muy unidas sin conocerse. Para sacarlos del molde, se desprenden por abajo, y se sacan volviéndolas del revés; luego se igualan con unas tijeras y se ribetean con una cinta estrechita de seda; poniendo otra cinta o cordoncito de seda dentro de la jaretita que deben llevar; y después se guardan para el uso»38.

En todo caso, la literatura pornográfica clandestina de la primera mitad del siglo XIX se refiere, casi siempre en ambientes prostibularios, a la presencia y utilización de condones por los clientes. Pero aún parece necesaria una mínima explicación, por si el lector no estuviera aún al tanto. Es el caso, por ejemplo, de la novela Adela prostituta y buena esposa, publicada hacia 1830 , en donde se refiere que algunos hombres "han querido condones o camisas que llaman a unas bolsas de piel muy sutiles, con las cuales cubren su miembro y joden con aquel embarazo para estar más seguros de no recibir contagio» 39 .

Del mismo modo, el autor anónimo de Las putas y Alcabuetas de Madrid (1839) alude a un "tripajo", explicitando en una nota que se trata de un "condon», que «los eclesiásticos [...] usan para no dejar preñadas a sus amas, y otros para preservar del mal venéreo", dejando claro por lo tanto ambas funciones

38 [IZQUIERDO GUERRERO DE TORRES, José R.]: Recuerdos de mi vida Con otras varias apuntaciones curiosas; que principian diariamente desde el día $1^{\circ}$ de $E n^{\circ}$ de 1836 con mapas, viñetas y lam Escrito por $D^{n}$ J. R. Y. en Londrès, 1836, mss. (Biblioteca Nacional, Madrid, Manuscritos, $\mathrm{n}^{\circ} 18.150$ ), t. I, pp. $43-$ 46 («Misceláneas del mes de Febrero»). Hemos intentado modernizar la ortografía y la puntuación. Las cursivas vienen en el texto original como subrayados.

39 Adela prostituta y buena esposa. Obra orijinal española ballada en una tumba del Monasterio de Santa Cruces, en Cataluña, escrita por ella misma, y adornada con láminas por el que la publica, Perpiñan, Imprenta y litografia de Alsina, s.f. [c. 1830], p. 12. 
desempeñadas por el preservativo masculino ${ }^{40}$. $Y$ no es seguramente un azar, por otra parte, si la alhacueta gaditana de una comedia clandestina se apellida La Tripona ${ }^{41}$.

Si no figura en los diferentes diccionarios publicados en el siglo XIX por la Real Academia, siempre mojigata, la voz «condón» viene registrada a mediados del siglo XIX en algunos diccionarios como en el diccionario francés-español publicado en 1845 bajo la dirección de Ramón Joaquín Domínguez, quien también incluye la palabra en su Diccionario nacional o Gran diccionario clásico de la lengua española, «el más completo de los léxicos publicados hasta el día» según Palau ${ }^{42}$ :

«Condom s. m. kon-don. Condon; preservativo contra el virus o mal venéreo. Sinónimo de Redingote o capote anglaise» ${ }^{43}$.

\section{¿PRESERVATIVO ANTIVENÉREO O MEDIO ANTICONCEPTIVO?}

Aún a finales del siglo XVIII, se consideraban las enfermedades venéreas como un azote divino para castigar los desórdenes humanos. Y, a mediados del siglo XIX, varias publicaciones pretendiendo detener «el verdadero preservativo del mal venéreo» dan cuenta del temor social producido entonces por las enfermedades venéreas contra las cuales no se disponía entonces de ningún tratamiento realmente eficaz:

«El mal venéreo es una de las dolencias más terribles que pueden afligir al género humano. Ella envenena el principio de la vida [...], ella perturba la paz doméstica, especialmente la conyugal, ella enerva las generaciones, ella anticipa la vejez y ella por último, llena los cementerios de cadáveres [...]»44.

40 Las putas y Alcahuetas de Madrid; Obra clásica en su género con láminas. Por Don Casto Cascósela y Pingalisa, doctor en Galilea, natural de Jodar, Segunda edición: corregida y aumentada por un español amante de la prosperidad de las artes, y muy versado en la materia, Roma [¿Madrid?], Imprenta del Colegio Putesco, 1839, pp. 11-12. Ver GuEREÑA, Jean-Louis: «Literatura y prostitución en el siglo XIX. De la novela folletinesca a la literatura clandestina», en FERNÁNDEZ, Roberto y SOUBEYROUX, Jacques (Eds.): Historia social y literatura. Familia y clases populares en España (siglos XVIII-XIX), Lleida, Editorial Milenio-Université Jean Monnet, 2001, pp. 170-173.

41 La Tripona o la Casa de Trato. Comedia en un acto original y en verso, Bayona, Imprenta de Jodiguelos, a cargo de don Cipote, 1850, 32 p. Ver GUEREÑA, Jean-Louis: «Literatura y prostitución en el siglo XIX", op. cit., pp. 173-174.

42 Domínguez, Ramón Joaquín: Diccionario nacional o Gran diccionario clásico de la lengua espanola, $4^{a}$ ed., Madrid, Establecimiento tip. de Mellado, 1850 [1 ${ }^{a}$ ed., 1847], t. I, cit. por CELA, Camilo José: Diccionario secreto. Tomo II Series Pis y afines, op. cit., p. 617.

43 DOMÍNGUEZ, Ramón Joaquín: Diccionario universal francés-español, por una sociedad de profesores de ambas lenguas, bajo la dirección de D. --, t. I, Madrid, Imprenta de la Viuda de Jordán e hijos, 1845, p. 585.

${ }^{44}$ Verdadero preservativo del mal venéreo por D. J. G., El Ferrol, Imp. de Don Nicasio Taxonera, 1847 , p. 10. 
Tras la muerte de Fernando VII, en esta nueva etapa política que se abría para España en 1833, iban a multiplicarse desde luego las obras sobre venereología, claro índice de nuevas preocupaciones sociales ${ }^{45}$. A menudo, se trataba no obstante de traducciones del francés: de 54 obras publicadas sobre el tema entre 1834 a 1868, 20 eran así versiones traducidas.

Y si la verdadera obsesión por el contagio y el desarrollo de la sífilis y otras enfermedades venéreas, uno de los grandes temores del siglo XIX junto con el cólera ${ }^{46}$, iba a mover a médicos y a políticos decimonónicos, desde los tiempos del trienio constitucional, a proponer una nueva reglamentación de la prostitución, y a no contentarse con su mera y por otra parte ineficaz represión, dentro desde luego de una amplia y constante polémica entre partidarios y adversarios de la reglamentación ${ }^{47}$, la profilaxis individual, tanto física como química, será objeto, cuando menos, de una prudente discreción.

"No hay indivíduo sin pasiones, y aquella que nos conduce a perder la salud en la embriaguez del placer domina la sociedad entera», constataban en 1834 los traductores de un tratado francés de enfermedades sifilíticas para justificar su empresa frente a enfermedades con "causa y carácter específicos y peculiares» ${ }^{48}$. Y precisamente en razón de esta especificidad, se pasará rápidamente del solo tratamiento médico-farmacéutico de la enfermedad a su etiología, al análisis de los factores más propicios a su desarrollo, o sea al estudio de la prostitución ${ }^{49}$,

45 LLOPIS MíNGUEZ, Baltasar: Las publicaciones sobre venereología en la España isabelina (18341868) y su posición internacional, Tesis de doctorado, Universidad de Valencia. Facultad de Medicina. Cátedra de Historia de la Medicina, 1990, pp. 922-936. Agradecemos a su autor el habernos dejado consultar su trabajo aún inédito.

46 QuÉTEL, Claude: Le mal de Naples. Histoire de la syphilis, Paris, Seghers (Médecine et Histoire), 1986, 348 p.; CoRBIN, Alain: «Le péril vénérien au début du siècle: prophylaxie sanitaire et prophylaxie morale, Recherches (Paris), n 29 (diciembre de 1977 [L'baleine des faubourgs]), pp. 245283; CORBIN, Alain: «La grande peur de la syphilis», en BARDET, Jean-Pierre, BOURDELAIS, Patrice, Guillaume, Pierre, Lebrun, François y QuÉTel, Claude (Eds.), Peurs et terreurs face à la contagion. Choléra, tuberculose, syphilis $X I X^{e}-X X^{e}$ siècles, Paris, Fayard, 1988, pp. 328-348.

47 CASTEJÓn BOLEA, Ramón: «Enfermedades venéreas en la España del último tercio del siglo XIX. Una aproximación a los fundamentos morales de la higiene pública», Dynamis (Granada), vol. 11 (1991), pp. 239-261, «Los médicos de la Higiene: Medicina y Prostitución en la España contemporánea (1847-1918)", Bulletin d'Histoire Contemporaine de lEspagne (Aix-en-Provence), $\mathrm{n}^{\circ} 25$ (Junio de 1997 (Prostitución y sociedad en España. Siglos XIX y XX]), pp. 73-87, y Moral sexual y enfermedad: La medicina española frente al peligro venéreo (1868-1936), Granada, Universidad de Granada-Instituto Alicantino de Cultura «Juan Gil-Albert», 2001, pp. 27-33.

48 MÉNDEZ, D. S. y WeILER, D. F.: "Prólogo» a LAGNEAU, L. V.: Tratado práctico de las enfermedades sifilíticas, que contiene los diferentes métodos de tratamiento que les son aplicables, junto con las modificaciones que éstos sufren por razón de la edad, sexo, temperamento, climas, estaciones y enfermedades concomitantes. Obra en la que se hallaran especialmente detalladas las reglas de tratamiento adoptadas en el Hospital de venéreos de París, Traducida de la sexta edición francesa, vol. 1, Barcelona, Imprenta de la Viuda e Hijos de Gorchs, 1834, sin p.

49 GIRAUDEAU DE SAINT-GeRvaIS, M.: Resumen histórico-moral de la prostitución, y de su estado actual en París; e influencia de la misma en la propagación de las enfermedades venéreas, escrito en francés por --,

Hispania, LXIV/3, núm. 218 (2004) 869-896 
sobre todo tras la publicación en París en 1836 del famoso libro de ParentDuchatelet sobre la prostitución parisina ${ }^{50}$, reseñado en España poco tiempo tras su publicación por Serapio Escolar ${ }^{51}$. Un año más tarde, este médico de los hospitales militares de Madrid publicaba una traducción «corregida y consideralemente adicionada» del Manual práctico del mal venéreo del francés Jean Claude Bésuchet, sobre el cual volveremos ${ }^{32}$.

También en esta época, como ya se apuntó para principios del siglo XIX, algunos charlatanes intentaban aprovecharse de la situación. Se conserva así un cartel de un tal Joaquín Carbó, fijado en Madrid el 17 de Julio de 1838, afirmando que las «víctimas de la intemperancia recobran su salud por mano de la filantropía»:

«QQué hombre amigo de la humanidad podrá mirar con indiferencia las víctimas que arrebata de contínuo la enfermedad venérea? ¿Quién podrá ocultar a sus compatriotas el específico, que ha sacado del borde del sepulcro a tantos, que contaban un período muy corto de vida? Yo tengo el placer de presentar este saludable antídoto, para alivio de la humanidad afligida, y la apología de su eficacia está en innumerables personas que viven por él. Estamos en el siglo de lo positivo; así que tendré la mayor satisfacción de probar la verdad de mi aserto a todo sujeto que quiera cerciorarse en mi casa morada, en la Puerta del Sol $\mathrm{N}^{\circ} 22 \mathrm{c}^{\text {to }} 3^{\circ}$ de la derecha» 53 .

En 1845, Carbó solicitaba «al Gobierno privilegio exclusivo para la venta del específico antivenéreo que posee», permiso que lógicamente le fue denegado, pasando el asunto a manos de un Juez de primera instancia ${ }^{54}$.

Si nos atenemos al discurso médico difundido en España desde los años treinta del siglo XIX, podemos observar la general hostilidad —cuando no el mero silencio de por sí descalificativo- observada en el siglo XIX e incluso a principios del XX por la mayoría de los médicos y de los higienistas españoles como por cierto de sus homólogos franceses vertidos al castellano. Cuando se

Traducido libremente al castellano por un profesor en medicina y cirugía, Barcelona, Imprenta y librería de J. Roca y Ca $, 1844,190$ p.

50 PARENT-Duchatelet, A.-J.-B.: De la prostitution dans la ville de Paris, considérée sous le rapport de Ihygiène publique, de la morale et de ladministration; ouvrage appuyé de documents statistiques puisés dans les archives de la Préfecture de police, Bruxelles, Etablissement encyclographique, 1837, XVI-392 p.

51 S. E. y M. [EsCOLAR Y MORALES, Serapio]: «De la prostitución», Boletín de Medicina, Cirugía y Farmacia. Periódico oficial de la Sociedad Médica General de Socorros Mutuos (Madrid), t. V (1838), pp. 78-80.

52 BÉSUCHET DE SAUNOIS, Jean-Claude: Manual práctico del mal venéreo, o cura racional de las enfermedades sifilíticas, arreglado al estado actual de los conocimientos médicos, y puesta al alcance de toda clase de personas, $2^{\mathrm{a}}$ ed., Madrid, Imp. de los hijos de Doña C. Piñuela, 1839 [1 ${ }^{\mathrm{a}}$ ed., traducida por Segundo GÓMEZ, 1833], 248 p.

${ }^{53}$ Archivo de la Real Academia de Medicina, Madrid, Leg, $n^{\circ} 9 \mathrm{C}$, doc. $\mathrm{n}^{\circ} 41 \mathrm{~B}$.

54 Real Academia de Medicina, Madrid, Sesión ordinaria del 3-III-1845 y 1-XII- 1845. 
llegaba a mencionar la existencia del condón, siempre o casi siempre era para insistir sobre su ineficacia, nunca para referirse a su - relativa- eficacia ${ }^{55}$.

Por ejemplo, en la primera traducción española, a cargo de Segundo Gómez, publicada en 1833, del Manual práctico del mal venéreo del ya mencionado Jean-Claude Bésuchet, dentro del apartado dedicado a exponer «si hay medios de preservarse del mal venéreo», se señalaba desde luego que «hay otra especie de preservativo para los hombres, que consiste en ponerse un cuerpo extraño para impedir el contacto inmediato de los órganos de la generación», para advertir a continuación que «los que se han servido de esta precaución, saben también lo que pueden confiar en su eficacia», o sea prácticamente nada ${ }^{56}$.

La misma idea iba a repetirse continuamente a lo largo de las décadas siguientes. No cabe olvidar desde luego que el preservativo de entonces en cuero, e incluso los primeros de caucho a finales del siglo XIX, distaban mucho de alcanzar las cuotas actuales en materia de seguridad.

En 1835, el autor anónimo (pero muy verosímilmente Enrique Atayde y Portugal, quien formaba parte de la redacción de la Gaceta Médica de Madrid, siendo posteriormente uno de los directores de los Anales del Instituto Médico de Emulación de 1842 a 1844) de un artículo publicado en la Gaceta Médica de Madrid, revista fundada un año antes, advertía que «los estragos que causa la sífilis o mal venéreo, y lo generalizado que se halla, son dos motivos graves, para buscar ya preservativos, ya medios de disminuir sus tristes efectos ${ }^{57}$ :

«Partiendo del supuesto de que los líquidos segregados son el vehículo de la enfermedad, se presentaba naturalmente dos especies de medios; a saber, impedir a las partes genitales el contacto con dichos líquidos, o hacer que estos experimenten una descomposición cualquiera. Para conseguir lo primero se han usado varios medios que son conocidos y que en general son bastante infieles»s8.

Pero nada concretaba en torno al preservativo masculino, ni incluso su denominación, ya relativamente popularizada como hemos visto.

Doce años más tarde, el autor anónimo del folleto titulado Verdadero preservativo del mal venéreo, después de haber tratado ampliamente de «los diversos modos de infección del mal venéreo», abordaba «el verdadero medio con que

55 LLOPIS MíNGUEZ, Baltasar: Las publicaciones sobre venereología en la España isabelina (18341868), op. cit., t. II, pp. 985-994 («Profilaxis de las enfermedades venéreas»); CASTEJÓN BOLEA, Ramón: Moral sexual y enfermedad, op. cit., pp. 150-171 («La prevención individual: abstención sexual y profilaxis física y química»).

56 BÉSUCHET, J.-C.: Manual práctico del mal venéreo o Cura racional de las enfermedades sifilíticas arreglada al estado actual de los conocimientos médicos y puesta al alcance de toda clase de personas, Obra escrita en francés por -- y traducida al español por Don Segundo Gómez, Madrid, Imprenta calle del Amor de Dios, 1833, pp. 10-11.

57 E. A. [ATAYDE, Enrique]: «Higiene pública. Sifilis. Preservativos: policía médica relativa a la propagación de este mal», Gaceta Médica de Madrid (Madrid), nº 1 (6-VI-1835), p. 59.

58 Ibid.

Hispania, LXIV/3, núm. 218 (2004) 869-896 
poder atravesar sin peligro tan borrascoso golfo», asegurando que «los bajeles de más alto bordo suelen naufragar en él, y que sólo la estricta observancia del sexto precepto del Decálogo es el único preservativo" 59 . Nada extraño pues que afirme, en estrecho paralelo con las fórmulas ya utilizadas por otros autores, que «en cuanto a la interposición sexual de ciertos cuerpos extraños para impedir el contacto de las partes sanas con las enfermas, los mismos que de ellos se han servido han reconocido también su inutilidad», al igual que «las abluciones acuosas antes y después del coiton" ${ }^{60}$.

En cambio, y a pesar de su título que podía dar a pensar que iba a tratar más o menos directamente del asunto, las publicaciones de Samuel La'Mert traducidas en 1850 acerca de La preservación personal y El preservativo personal eran totalmente mudas acerca de la profilaxis antivenérea por medio de los preservativos físicos ${ }^{61}$.

En 1861, el médico Antonio Prats y Bosch, socio corresponsal de la Academia de Medicina y Cirugía de Barcelona y de la Academia Médicoquirúrgica matritense, iba a ser algo más concreto y prolijo, pero llegaba a la misma conclusión que sus predecesores, impulsado más por convicciones morales de índole religiosa que por motivaciones médicas, entresacadas de su experiencia profesional:

«[...] Muchos son los que han creído que el medio más seguro de oponerse al contagio era impedir el contacto inmediato entre los genitales del hombre y los de la mujer. Y de aquí que unos hayan preconizado las fricciones con ungüento mercurial, como aconseja Astruc, o con aceite de olivas, como ordena el reglamento de Bruselas; y otros hayan recomendado el uso de las bolsas membranosas inventadas por Mister Condom. Cúmplenos decir, sin embargo, que ambos medios están distantes de ser preservativos seguros de la sífilis, y que todavía están muy lejos de tener el grado de eficacia que se les supone por la generalidad. [...] Y équé diremos del invento de Mister Condom, de esa «coraza para el placer y telaraña para el peligro, que, según la feliz expresión del profesor del hospital del Mediodía, es un mal paraguas que puede romperse en medio de la tormenta, y que en todos los casos, librando bastante mal de la lluvia, deja que los pies se cubran de lodo? ¿No son varios los indivíduos que, a pesar de servirse de tal medio, han visto aparecer un

59 Verdadero preservativo del mal venéreo, op. cit., pp. 52-53.

60 Ibid., pp. 54-55.

${ }^{61}$ LA'MERT, Samuel: De la preservación personal, o Tratado sobre las enfermedades de los órganos genitales, producidas por los vicios ocultos, los escesos de la juventud, o el contagio; y observaciones sobre la impotencia prematura, Traducido de la trigésima quinta edición adornado con cuarenta láminas inglesas, Única traducción aprobada por el autor y aumentada considerablemente por el mismo, Madrid, C. Monier, Editor, 1850, XXXIV-139 p. (existe una traducción anterior en 1849), y El preservativo personal. Tratado médico sobre las enfermedades de los órganos de la generación que resultan de los hábitos secretos, de los escesos de la juventud, o del contagio aumentado con observaciones prácticas sobre la impotencia prematura etc. etc. $y$ adornada con láminas intercaladas en el texto, Por el Doctor -- y vertido del francés al español por D. Antonio PujADAS, Barcelona, Imprenta y Librería de Manuel Saurí, 1850, 176 p. 
chancro en el pubis o en la raiz del pene? ¿Qué seguridad y qué valor les debe infundir por consiguiente para exponerse sin miedo al contagio?

[...] De todo lo expuesto se deduce que en la actualidad no se conoce medio alguno seguro para librarse del contagio sifilítico, que algunos de los que se preconizan son poco eficaces, que otros son completamente engañosos, y que alguno, no sólo carece de fundamento científico, sino que además es altamente contrario a los preceptos de la moral»62.

Ya durante el sexenio revolucionario, en su memoria leída en julio de 1869 en el ejercicio para ser doctor sobre el tema «Qué medios deberá aconsejar el médico-higienista al Gobierno para atenuar los funestos efectos ocasionados por la prostitución?», Juan Marsillach y Parera se declaraba partidario, en la línea de Monlau, de «no reglamentar ni permitir el libertinaje, y mejor aún [...] no reglamentarle y reprimirle», ya que «el número de rameras crece cuando es tolerada la prostitución» ${ }^{63}$. Dentro de esta concepción, y si bien se declara partidario del derecho de los médicos en intentar encontrar «los preservativos específicos de la sífilis», afirma que «el preservativo por excelencia, el único seguro que por ahora se conoce es la continencia" ya que "para no contraer la sífilis no hay como huir de ella» ${ }^{64}$. Menciona desde luego la existencia del condón, pero advirtiendo que se encuentra entre los medios «reprobados por la moral» y que su eficacia es muy relativa desde un punto de vista médico:

«[...] No defiende el escroto, ni el pubis, ni la parte superior interna de los muslos, y $[\ldots]$ puede agrietarse fácilmente, y hasta permitir la absorción del vírus sifilítico al través de los poros de su ténue tejido»65.

Semejante prevención frente al condón seguía repetida más de diez años más tarde. En la traducción de la obra del venereólogo francés Edmond Langlebert dedicada a la instrucción de la juventud, Cartas a Emilio, sobre el arte de preservarse del venéreo y de los charlatanes que lo explotan, publicada en 1881, se pasa así a describir las formas de preservarse del contagio venéreo tras exponer el origen de las enfermedades venéreas y los diversos síntomas y signos a los que puede dar lugar. Y lo que primero recibe su atención es el condón, del que opina que «mejor sirve para encubrir el peligro que para preservarnos de él» y al que no duda en rechazar tajantemente, mezclando razones médicas y morales:

62 Prats y BOSCH, Antonio: La prostitución y la sifilis: Ensayo acerca de las causas de la propagación de las enfermedades sifiliticas y los medios de oponerse a ella, Barcelona, Librería de El Plus Ultra, 1861, pp. 67-71.

63 MARSIllach y PARera, Juan: Tema $n^{0} 36$ ¿Qué medios deberá aconsejar el médico-bigienista al Gobierno para atenuar los funestos efectos ocasionados por la prostitución? Memoria que en ejercicio para el grado de doctor en Medicina y Cirugía leyó el día $1^{\circ}$ de Julio de 1869 D. --, Barcelona, Establecimiento tipográfico de Jaime Repús Roviralta, 1869, pp. 13, 19 y 29.

64 Ibid., pp. 24-25.

65 Ibid., pp. 25-26.

Hispania, LXIV/3, núm. 218 (2004) 869-896 
«Si la fina película de tripa de buey o la delgada capa de cautchu [sic] que lo forman, son de calidad bastante buena para resistir a la lucha, icómo impedir que no se pliegue sobre sí mismo o que no abandone su puesto y nos deje entonces completamente descubiertos contra un enemigo que, sin su ayuda, sin el incentivo de una falsa seguridad, de fijo hubiéramos evitado no exponiéndonos de ningún modo a él? Por todas estas razones y otras más que el decoro nos invita a pasar en silencio, condenamos resueltamente el uso de este preservativo, más propio para provocar la repugnancia que para inspirar el deseo de una función, en la que suprime a la vez el objeto y el atractivo principal»66.

En 1887, se verifica en el seno del Instituto Médico Valenciano una discusión sobre la profilaxis pública de la sífilis. En el transcurso de la sesión del 3 de diciembre de 1887, el Dr. López Gimeno propuso en su intervención, "para evitar el contagio a los sanos, [...] no efectuar el coito si existe alguna solución de continuidad en los órganos genitales, el lavado de los mismos, embadurnamiento con sustancias grasas, etc.», enumerando a continuación «la cauterización, el líquido de Langlebert que otros proponen, y el propuesto por Condón, usado sólo como preservativo de la sífilis, pero que no aconsejó» ${ }^{67}$.

Esta actitud más que cautelosa de la clase médica venía reflejada e incluso acentuada en las colecciones populares de divulgación sexual que se multiplicaron a partir de finales del siglo XIX ${ }^{68}$. Así, el Dr. V. Suárez Casañ dedica uno de los fascículos de su colección «Conocimientos para la vida privada» al llamado Onanismo conyugal, señalando entre "los fraudes directos» (a la generación) «el uso del envoltorio inventado por el doctor Condom», advirtiendo que «el procedimiento que consiste en el empleo del envoltorio llamado condón, es uno de los más empleados por las clases acomodadas y también uno de los que mayores peligros traen consigo" ${ }^{69}$. Tal noción de «fraude» viene utilizada también en otra colección de divulgación sexual, la Biblioteca privada ${ }^{70}$.

A principios del siglo XX, Ángel Pulido opinaba que el condón, aunque efectivo cuando era utilizado en las condiciones adecuadas, era rechazado por diversos autores por disminuir el placer sexual y por cuestiones morales al considerar que su utilización convertía el acto sexual en una forma de «onanismo» ${ }^{71}$.

\footnotetext{
${ }^{66}$ LANGLEBERT, Edmundo: Cartas a Emilio, sobre el arte de preservarse del venéreo y de los charlatanes que lo explotan. Parte complementaria de todos los tratados de educación destinados a los jóvenes, Versión española por Álvaro ARNAU, Valencia, Imprenta de Manuel Alufre, 1881, pp. 34-35. Ver también p. 75.

${ }^{67}$ Boletín del Instituto Médico Valenciano (Valencia), t. XX (1887), p. 377.

${ }_{68}$ Ver GUEREÑA, Jean-Louis: «Le sexe dévoilé. Les collections populaires d'éducation sexuelle au début du XX $\mathrm{XX}^{e}$ siècle» (en prensa).

69 SuÁREZ CASAÑ, Dr. V.: Onanismo conyugal, $21^{\mathrm{a}}$ ed. corregida y aumentada por el doctor Pío ARIAS-CARvajal, Barcelona, Casa Editorial Maucci (Conocimientos para la vida privada, Primera serie, IV), s.f. [1 ${ }^{\mathrm{a}}$ ed., 1894], pp. 14-15.

70 MAntegazZa y ANDRAde: Los fraudes en amor, Versión española de Pedro F. OROL, Barcelona, Centro Editorial La Vida Literaria (Biblioteca privada, 14), s.f. [c. 1900], 96 p.

71 Pulido Martín, Ángel: «Profilaxis blenorrágica», El Siglo Médico (Madrid), art. reproducido en Revista Española de Dermatología y Sifilografía (Madrid), vol. 10 (1908), pp. 318-323.
} 
Del mismo modo, un sifiliógrafo francés, Louis Jullien, seguía considerando en 1909 que la utilización del condón «ofrece una garantía relativa, limitada solamente a los sitios protegidos y a condición de su integridad absoluta» y le parecía de todas formas «bastante repugnante por sí misma» ${ }^{72}$.

Sólo a partir de los años diez, se encuentran opiniones médicas algo favorables a la utilización del preservativo masculino. Por ejemplo, el Dr. García Puelles podía afirmar en 1913 que «el condón, medio mecánico de protección, que, bien colocado, es el más seguro, siempre y cuando no se rompa; pero que tiene el inconveniente de repugnar a muchos, por la acción inhibidora que en ellos ejerce durante el acto venéreo» ${ }^{73}$.

Pero las opiniones contrarias eran constantes. En 1919, Eleuterio Mañueco Villapadierna, según el cual la profilaxia personal debía realizarse a través del médico de familia, consideraba la protección del condón limitada porque no recubría la raiz del pene ni la zona pubiana ${ }^{74}$. Y a un médico de la profilaxis oficial antivenérea como Eduardo de Gregorio, el condón seguía planteando, como método para la prevención de la sífilis, el problema de que protegía exclusivamente el pene y que su utilización conllevaba en la mayoría de los casos el abandono de otras prácticas preventivas, incluido el lavado jabonoso de los genitales 75 .

En los años treinta, tal opinión no era compartida, desde luego, entre todos los médicos. Así, Manuel Garriga consideraba que «durante las relaciones sexuales, el empleo del preservativo constituye uno de los recursos profilácticos más seguros», si bien reconocía que "puede a veces efectuarse el contagio en la piel de la raiz del miembro y de la cara interna de los muslos» ${ }^{76}$. A Julio Bravo, médico también de la lucha antivenérea, le parecía que el condón no ofrecía en la sífilis tanta eficacia como en la gonorrea, y José Gay Prieto, catedrático de la Universidad de Granada, pensaba en 1934 que el lavado jabonoso detenido y practicado inmediatamente después del coito igualaba en eficacia al condón y a la pomada de Mechnikoff, y les superaba en comodidad $^{77}$.

En 1931, A. Cordero Soroa, médico de los dispensarios antivenéreos de Madrid, sintetizaba de este modo la validez de los métodos de profilaxis individual, rehabilitando — medicalmente hablando- el uso del condón:

\footnotetext{
72 Jullien, Louis: El «Terrible Mal». Confidencias de un médico, Madrid, Librería de los Sucesores de Hernando, 1909, p. 320

73 García Puelles, Dr.: «Profilaxis de la blenorragia», Medicina Española, art. reproducido en Revista Española de Dermatología y Sifiliografía, vol. 15 (1913), n 179, pp. 620-625.

74 MaÑueCo Villapadierna, Eleuterio: «Profilaxia personal de las enfermedades venéreas», El Siglo Médico (Madrid), vol. 66 (1919), p. 1078.

75 CASTEJÓN BOLEA, Ramón: Moral sexual y enfermedad, op. cit., p. 165.

76 GARRIGA, Manuel: El tratamiento de la sífilis en los periodos primario y secundario, Barcelona, Ed. Labor, 1930, p. 130.

77 GAY PRIETO, Dr. José: Las enfermedades venéreas y sus profilaxis, Madrid, Editorial Cenit (Biblioteca de vulgarización médica), 1934, p. 67.
} 
«Queda en pie el valor indiscutible de los lavados jabonosos precoces y prolongados, la utilidad de la profilaxis mecánica por el preservativo o condón y el poco o nulo valor profiláctico de las diferentes pomadas propuestas y comunmente en uso»78.

No hay que olvidar desde luego que métodos profilácticos físicos como el condón eran además métodos anticonceptivos, lo que puede explicar, en parte, las reticencias de los médicos a una verdadera difusión popular del mismo y la insistencia en considerar la abstención sexual como el mejor método profiláctico.

A partir de los años veinte, con el desarrollo de la propaganda neomaltusiana, varias obras, a menudo de autores extranjeros, exponían ya sin tapujos - no sin criticarlas a veces - los diferentes métodos para hacer el amor «sin peligros». El preservativo entraba por lo tanto dentro de las estrategias anticonceptivas y de lo que aún no se llamaba la planificación familiar.

Citemos, por ejemplo, los libros de Galtier y Sutor, de Marie Stopes, de Esteban Laguna, de W. Wasroche o de G. Hardy ${ }^{79}$. Y en los años treinta, el «birth-control» era ya totalmente asumido por varios autores, como Hildegart, Luis Huerta y otros, con especial énfasis dentro del movimiento de "Generación Consciente» nacido en Alcoy ${ }^{80}$ :

78 CORDERO SOROA, A.: «Orientación moderna en la profilaxis individual de las enfermedades venéreo sifilíticas (Conferencia pronunciada en el Hospital de San Juan de Dios, en los servicios del doctor Sáinz de Aja)", Ecos Españoles de Dermatología y Sifiliografía, vol. 7 (1931), nº 74, pp. 99-110.

79 GAlTIER Y SUTOR, Dres.: El libro del amor sin peligros. Primera parte: Preservación contra las enfermedades venéreas. Segunda parte: Preservación contra los peligros del embarazo. Edición profusamente ilustrada, Barcelona, Editorial A.L.S.A., s.f. [c. 1920], pp. 163-166 («Medios mecánicos»); STOPES, Marie Carmichael: Contracepción (Regulación de los nacimientos). Su teoría, bistoria y práctica. Obra utilísima para los cónyuges y de especial interés para los médicos, practicantes, profesoras en partos, enfermeras y abogados, Introducción por el Profesor Sir William BAYLISS, Notas de introducción por Sir James BARr, Dr. C. Rolleston, Dra. Jane Hawthorne y ObSCurus, Ilustrada con 14 grabados, Traducción del inglés, Barcelona, Antonio Roch-editor, s.f. [c. 1923], pp. 123-128; LAGUNA, Dr. D. Esteban: Guía médico-sexual (Para evitar los peligros o consecuencias del amor), Barcelona, Biblioteca de divulgación sexual, 1927, 78 p.; WASROCHE, Dr. W.: Amor sin peligros, Barcelona, Editorial «Dédalo» (Biblioteca Científico Sexual Ilustrada), s.f., pp. 62-64 («Medios mecánicos); HARDY, G.: El exceso de población y el problema sexual (Con un interesantísimo estudio acerca del Aborto, su necesidad, los procedimientos para llevarlo a efecto y los peligros que trae aparejados), Edición ilustrada con 66 grabados, Traducción del francés por J. ElIZALDE, Valencia, Biblioteca de Estudios, 1934, Libro III, «Los medios anticoncepcionales»: «Funda inglesa o condón», pp. 251-252; «Condones de tripa (película intestinal)», pp. 252-254; «Condones de caucho», pp. 254-256.

${ }^{80}$ Hildegart: Profilaxis anticoncepcional. Paternidad voluntaria, Valencia, Ediciones «Orto», 1931, 112 p. (existe una edición moderna: Medios para evitar el embarazo. Paternidad voluntaria, Edición preparada por los Drs. RonCalés Mateo, MiÑano NAVARRo, Gómez CalataYUd, Zaragoza, Guara Editorial, 1978, 126 p.); HUERTA, Luis: Natalidad controlada (Birth-control), Valencia, Cuadernos de Cultura (LXXVIII), 1933, 47 p.; SUTOR, Franck: Generación consciente. Anatomía, Fisiología, Preservación científica y racional de la fecundación no deseada, Obra ilustrada con 23 grabados en el texto, Alcoy, Biblioteca Editorial Generación Consciente, s.f., 62 p. Ver, entre otros, los estudios de NAVARro NAVARro, Francisco Javier: «Anarquismo y Neomalthusianismo: la revista Gene- 
«iGuerra a la miseria!

Engendrar hijos cuando no se dispone de medios suficientes para nutrirlos y educarlos debidamente, no sólo es una imprudencia y una vergüenza: es una infamia; es un crimen que sólo la ignorancia y la estupidez humana pueden disculpar.

No hay que confiar a la Suerte, diosa venerada por la imbecilidad, el cretinismo y la impotencia, que haga felices a toda esa podredumbre humana, a todo ese montón horrible de hijos no deseados, nacidos contra la voluntad de sus padres, y cuya existencia es un sufrimiento continuo [...]»81.

La literatura de divulgación sexual seguía exponiendo por supuesto los diferentes medios para controlar la natalidad. Citemos la famosa colección «Temas sexuales» (Madrid, 1932-1934, $60 \mathrm{n}^{\circ}$ ) a cargo del prolífico Ángel Martín de Lucenay ${ }^{82}$. En el volumen dedicado al control de natalidad, dentro del capítulo dedicado a exponer el «empleo de los contraceptivos», Martín de Lucenay recuerda el origen e historia de los preservativos, concluyendo que «[...] indudablemente, es el medio más seguro y cómodo de evitar el embarazo y el que se emplea en todo el mundo por los anticoncepcionistas» ${ }^{83}$.

Pero, ¿cuál podía ser la utilización de los condones («gomas») y otros preservativos en las prácticas sexuales de los varones españoles? En el siglo XIX, los preservativos parecen formar parte aún plenamente de lo que podríamos calificar de «cultura del burdel», ampliamente practicada por una mayoría de los varones españoles. Así, los encontramos mencionados repetidamente en una parodia pornográfica del Don Juan Tenorio de $1874^{84}$, o en otra parodia hacia 1880, la del Diablo mundo de Espronceda ${ }^{85}$. En cambio, no parecen sino haber tenido entonces un uso limitado en el marco matrimonial.

ración Consciente (1923-1928)», Arbor (Madrid), t. CLVI (1997), n 615, pp. 9-32, y de MASJUAN, Eduard: «Procreación consciente y discurso ambientalista: anarquismo y neo-malthusiasnismo en España e Italia, 1900-1936», Ayer (Madrid), no 46 (2002), pp. 63-92.

81 iGuerra a la miseria!, Hoja volante, s.l. [Valencia], s.f. [c. 1930].

82 Ver Gonzalo SANTONJA, «La Editorial Fénix (Madrid, 1932-1935). Notas sobre la literatura de quiosco durante la II República", en Literatura popular y proletaria, Sevilla, Universidad de Sevilla (Colección de bolsillo, 95), 1986, pp. 209-246 («La serie «Temas Sexuales» y el doctor Martín de Lucenay, apócrifo diplomado en sexología», pp. 219-226; «Problemas» y «La cuestión sexual», pp. 226-231).

83 MARTín De LuCENAY, Dr. A.: El control de natalidad, Madrid, Editorial Fénix (Temas sexuales, 16), 1933, p. 62.

${ }^{84}$ [Ambrosio el De la CARABina]: Don Juan Notorio. Burdel en cinco actos y 2.000 escándalos por Abí me las dén todas, San Lúcar de Barrameda [¿Barcelona?], Establecimiento Jodeográfico Ultramontano, $1874,40 \mathrm{p}$.

85 MONTADO, Alejo de [¿Eduardo Lustonó?]: Parodia cachonda de «El diablo mundo» de Espronceda, por Alejo de Montado. Miembro robusto y erguido de la «Sociedad Virguera» del Olimpo, catedrático por oposición en la Universidad libre de Sodoma; socio corresponsal del Instituto culográfico de Nápoles; presidente honorario de la Academia del "Bello Placer», caballero gran cruz de la empinada orden de «Príapo, cruz y placa de la del Monte de Venus"; cruz sencilla del mérito rojo del menstruo de la casta Susana; cojonudo autor de varias obras morales, etc., etc., Olimpo, Imprenta Mitológica, s.f. [c. 1880], pp. 3, 4, 14, 18, 36 y 43.

Hispania, LXIV/3, núm. 218 (2004) 869-896 


\section{PUBlicidades y CATÁLOGOS DE PRESERVATIVOS}

Las publicidades aparecidas en la prensa, desde principios del siglo XX, y la existencia de varias casas especializadas con sus correspondientes catálogos y venta por correspondencia, demuestran no obstante una progresiva utilización popular de los preservativos en las prácticas sexuales de los españoles ${ }^{86}$, tanto como protección antivenérea -a menudo afirmada por dichas publicidades «higiénicas»- que como medio anticonceptivo, siempre solapado en el discurso publicitario que insiste reiteradamente en la excelente calidad y en la absoluta seguridad de sus productos, totalmente «irrompibles».

Hacia 1900, parece ser que los preservativos de cuero seguían fabricándose en España frente a los de caucho de origen norteamericano o alemán, y podemos referirnos pues a la existencia de un mercado específico, con sus circuitos más o menos clandestinos situados preferentemente en las zonas de concentración prostibularia, como el famoso «Barrio chino» barcelonés ${ }^{87}$.

Desde principios del siglo XX, son relativamente frecuentes, pues, en la prensa festiva, pero también en diarios de información general, anuncios publicitarios de marcas de preservativos masculinos (entonces casi siempre calificados de "gomas higiénicas») y a sus catálogos. En el semanario La Hoja de parra, se podían encontrar, por ejemplo, publicidades de este tipo en los años 1913-1914:

«SEGURIDAD ABSOLUTA/ La tendréis si usáis las gomas higiénicas que vende/ LA MASCOTA/ GATO, 4./ Catálogo gratis enviando sello»88;

«EL FENÓMENO/ sigue bien desde que compra go-mas irrompibles de las mejores/ marcas que vende/ LA INGLESA/ San Vicente, 164, Valencia./ Catálogo gratis enviando sello»89;

«LA INGLESA/ Primera casa en gomas higiénicas./ MONTERA, 35, (Pasaje)/ y VICTORIA, 3, Ortopedia./ Catálogo gratis enviando sello» 90 .

Pero este mismo tipo de publicidad podía leer también en diarios conocidos como en $E l$ Sol, una de las empresas periodísticas del filósofo José Ortega y Gasset [1883-1955], en 1922-192391:

\footnotetext{
86 Ver ABELLO I GUELL, Teresa: «El control de la natalitat com a mitjà revolucionari a principis de segle: un capítol de la medicina submergida", Gimbernat (Barcelona), vol. V (1985); FOLGUERA, Pilar: «Política natalista y control de natalidad en España durante la década de los veinte: el caso de Madrid», en GARCía NIETO, $\mathrm{M}^{\mathrm{a}}$ Carmen (Ed.): Ordenamiento jurídico y realidad social de las mujeres. Siglos XIX-XX, Madrid, Universidad Autónoma de Madrid, 1986; Álvarez Peláez, Raquel: «La mujer española y el control de la natalidad en los comienzos del siglo XX», op. cit.

87 VILLAR, Paco: Historia y leyenda del Barrio chino (1900-1992). Crónica y documentos de los bajos fondos de Barcelona, Barcelona, Edicions La Campana, 1996, pp. 140-142.

${ }^{88}$ La Hoja de parra (Madrid), no 129 (15-XI-1913), p. 16.

89 Ibid., $\mathrm{n}^{\circ} 149$ (4-IV-1914), p. 15.

${ }_{90}$ Ibid., no 179 (31-X-1914), p. 16.
} 
«Preservativos/ La casa mejor surtida en España: La Inglesa. Montera, 35 (pasaje). Catálogo gratis enviando sello» 92;

«GOMAS HIGIENICAS/ Catálogo gratis sin enviar sello. "LA DISCRETA.SALUD, 6"»93.

Desde luego, la prensa festiva y «galante» seguía publicando esta clase de anuncios al final de la dictadura y al principio de la $\mathrm{II}^{\mathrm{a}}$ República, como era el caso de Muchas Gracias, «Revista cómico-satírica» aparecida en 1924:

«PRESERVATIVOS alemanes garantizados "La Mundial", primera casa Barcelona, Espalter, 6. Remitiendo 3,50 sellos, envío discreto "seis" preservativos extra» 94 ;

«LA MASCOTA/ Casa dedicada a la venta de gomas higiénicas alemanas de las mejores marcas. Sin rival. Pruébenlas y se convencerán. Mata... insectos en polvo, 50 céntimos caja./ 1, San Ramón, 1- Barcelona/ Se remiten por Correo muy discretamente»95;

«PRESERVATIVOS completamente irrompibles. Dirigirse siempre Espoz y Mina, 32. «La Ideal». Clase especial, 2,50 docena»96;

«iALTO!/ Las mejores gomas higiénicas las vende LA MASCOTA/ Remítense por correo, previo envío de su importe:/ 6 clase morena 1,25/ 6 íd. marfil 2,50/ 6 íd. extrafina 3,00/ 1, San Ramón, 1.-Barcelona»97;

"ANATOMIC/ La docena ANATOMIC no 1 (goma fina) 8 pts/ ANATOMIC $n^{\circ} 2$ (lavable)...16 "/ ANATOMIC $n^{\circ} 3$ (triple finísima)...24 "/ ANATOMIC $n^{\circ} 4$ (3 muestras surtidas)...5 "/ Envío sellado con una muestra TALCO especial y catálogo ilustrado único (100 fotos) contra Giro postal/ Maison $\mathbf{M}$. BELLARD, Hygiène 22, Fg Montmartre, PARIS- $9{ }^{\mathrm{c}} \gg 98$;

«PRESERVATIVOS irrompibles LA PAJARITA, única que los garantiza. 3,50 pesetas docena. Barbará, 29, Barcelona. Envío reservado correo"99;

«GRATIS/ Recibirán seis preservativos "PUFF" completamente irrompibles como propaganda quien envíe este anuncio adjuntando 0,75 para gastos de envío

\footnotetext{
91 Raquel Álvarez señala también la presencia de publicidad para preservativos en El Socialista (Álvarez Peláez, Raquel: «La mujer española y el control de natalidad en los comienzos del siglo $\mathrm{XX}$, op. cit.).

${ }_{92}$ El Sol (Madrid), VI, n 1454 (6-IV-1922), p. 2/IV

93 Ibid., VII, $\mathrm{n}^{\circ} 1765$ (6-III-1923), p. 7.

${ }_{94}^{4}$ Muchas Gracias (Madrid), IV, nº 187 (9-IX-1927), p. 18.

95 Ibid.

96 Ibid., VI, nº 258 (19-I-1929), p. 18.

97 Ibid., VI, no 307 (28-XII-1929), p. 48

98 Ibid., VII, nº 333 (28-VI-1930), p. 22.

99 Ibid., p. 24.
}

Hispania, LXIV/3, núm. 218 (2004) 869-896 
certificado y discreto/ Dirigirse: Angel Pérez-Gil, 27 Melgar de Fernamental (Burgos)» 100 ;

«PRESERVATIVOS completamente irrompibles. Dirigirse siempre "La Ideal", Jardines, 23, Ortopedia. Clase especial, 2,50 docena»101;

«PRESERVATIVOS irrompibles, garantía absoluta, 5 pesetas docena. "La Pajarita". Bárbara, 29. Barcelona. Envío reservado correo»102;

«LA INGLESA. Barcelona, San Pablo, 18. La más importante. Preservativos finos, irrompibles, lavables. Remite reservadamente correos todas partes. Docena, $5,00,10,00,20,00$ pesetas, abonándolos cartero recibirlos»103;

«PROTECCION verdadera la proporcionan los preservativos que vende «La Discreta», Salud, 6, Madrid. Catálogo gratis»104.

Podemos observar, junto a casas madrileñas y barcelonesas, la presencia de una casa burgalesa y también de una casa parisiense que disfrutaba de la fama asociada a la «ciudad de los placeres». No era pues difícil, desde principios del siglo XX, adquirir preservativos en la mayoría de las ciudades españolas, donde, en torno a las zonas tradicionales de prostitución, existía algún Bazar Médico o Casa Ortopédica que facilitaba, con relativa discreción, este tipo de productos.

No sólo la prensa constituía un medio publicitario habitual para la venta de preservativos. Cualquier ocasión podía ser buena. Entre los años de 1929 a 1933, la casa valenciana La Inglesa, fundada en 1900, se anunciaba así como «la casa que vende las mejores gomas higiénicas» nada menos que en los programas oficiales de la Semana Santa Marinera, fiesta patrocinada por el ayuntamiento valenciano. En el programa de 1931, la propaganda añadía que las gomas eran «completamente irrompibles» ${ }^{105}$. Del mismo modo, y siempre en Valencia, la casa La Oriental, «situada en el punto más céntrico y discreto de Valencia», se anunció en el programa de las fiestas falleras como la que vendía los mejores preservativos y en donde se podía encontrar «toda clase de artículos para la higiene».

Durante la II ${ }^{\mathrm{a}}$ República, se generalizó y banalizó pues la publicidad a favor de los preservativos y de los medios anticonceptivos en general, como en Barcelona hacia 1934-1935, lo cual podía aparecer a algunos como una verdadera provocación:

«En los abigarrados quioscos de sus ramblas se exhibían sin recato ilustraciones y textos que incitaban, bajo títulos más o menos extravagantes o ladinos, a su

\footnotetext{
100 Ibid., VIII, nº 403 (21-XI-1931), p. 20.

101 Ibid., p. 22.

102 lbid.

${ }^{03}$ Ibid.

104 Ibid., p. 46.

105 Solaz Albert, Rafael: La Valencia probibida. Sexo vigilado en la ciudad, Valencia, Pentagraf, 2004. Agradecemos a su autor el habernos dejado consultar su manuscrito antes de publicación.
}

Hispania, LXIV/3, núm. 218 (2004) 869-896 
lectura y con ello a la propagación de una literatura, mala literariamente hablando y peor aún desde el punto de vista ético o demográfico. Allí, so pretexto de popularizar sanas prácticas profilácticas o enseñanzas técnico biológicas, se destacaban las bases de un maltusianismo crudo, descarado y anticristiano, o bien se hacía mera pornografía intolerable»106.

Muchos de estos anuncios, como se ha podido ver, apuntaban la existencia de un catálogo que estaban dispuestos a mandar de forma gratuita, en particular a quienes no vivían en una capital donde existía un establecimiento de tales características. Conocemos varios de estos catálogos, similares a los que existen entonces en otros países, en Francia por ejemplo ${ }^{107}$, gracias a los cuales el cliente podía comprar, sin moverses de su casa, preservativos con relativa discreción. Por supuesto, cada una de estas casas insistía en la máxima calidad de sus productos, alardeando de poder facilitar lo más novedoso en la materia.

Desde 1907, existe así en Madrid una casa de «ortopedia inglesa» que afirmaba poder «ofrecer a su numerosa clientela, artículos de primera calidad, y géneros recientemente fabricados, debido al mucho consumo por hacer las compras en ventajosas condiciones, y estar en relación directa con las principales fábricas extranjeras» ${ }^{108}$. Proponía así tanto modelos corrientes de preservativos (50 céntimos la unidad por una "goma», 75 céntimos por un preservativo de «seda inglesa» y 1 peseta de «tripa») como sus «modelos especiales» (de 1.50 a 3.50 pesetas). También proponía, entre otras especialidades foráneas (italianas, americanas y alemanas), y con un precio comprendido entre 4 y 7 pesetas la unidad, unos preservativos ingleses, «lavables, construidos con hoja inglesa de la mejor calidad» y de una «duración mínima» garantizada de un año:

«Estos preservativos tienen la duración mínima de un año, teniendo cuidado de desinfectarlos después de cada uso con agua tibia sublimada, e inmediatamente después secarlos bien y llenarlos de polvos de talco o fécula de patata por dentro y fuera, dejándolos así hasta que se vuelvan a usar, que se desocuparán los polvos y se arrollarán para su mejor colocación».

En 1911, la casa Hygins and Sanitary Co, antes F. B. Garcés y Cía, establecida en Barcelona, propone el catálogo de sus productos, entre los cuales destaquemos el preservativo «El caimán», «imitando la piel de cocodrilo», que «es

106 JIMÉNEZ AsENJO, E.: El anticoncepcionismo ante la moral y la ley penal, Madrid, Ediciones Hesperia, s.f. [1943], p. 5.

107 Préservatifs pour hommes, catalogue $n^{0} 1$, Paris, Société Excelsior, s.f. [c. 1900], 48 p.; «Préservatifs recommandés par les sommités médicales», publicidad al final de JAF, $\mathrm{D}^{\mathrm{r}}$ : Ovariotomistes et faiseuses d'anges, Paris, Librairie de la Nouvelle France (Collection de Psychologie populaire du $\mathrm{D}^{r}$ Jaf), s.f., $127 \mathrm{p}$

108 Ortopedia inglesa fundada en 1907. Victoria. 3-Madrid, s.l. [Madrid], s.ed., s.f., s.p. 
de lo más nuevo, curioso y útil que se conoce». Se vendía con o sin recipiente y en tres tallas (pequeño, mediano y grande) ${ }^{109}$ :

«El Caimán está fabricado con cauchú y seda sin soldadura de ninguna clase, y afelpado después por un nuevo procedimiento; este preservativo es del más gracioso efecto; y de una fineza extremada y una dulzura sin par al usarlo, no produciendo irritación alguna».

Del mismo modo, hacia 1920, La Reserva ofrece en Oviedo sus «preservativos (absolutamente irrompibles) contra enfermedades venéreas» ${ }^{110}$. También el Dr. J. Juan Pastor y el movimiento Generación Consciente, no contentándose por lo tanto con divulgar por escrito prodecimientos anticonceptivos, facilitaban desde Valencia "preservativos finísimos, resistentes, imperceptibles e higiénicos", no buscando por lo tanto la extremada sotisficación antes observada por casas comerciales:

«Hemos desechado los productos que no sean de calidad superior garantizada, y por lo tanto tenemos la seguridad de que nuestros preservativos, tanto por su finura, excelentes condiciones y sus precios ventajosos, serán de completa satisfacción de nuestros clientes. Todos los preservativos que ofrecemos proceden de las mejores marcas alemanas e inglesas acreditadas y de calidad inmejorable»11.

También facilitaba consejos acerca de la utilización y de la conservación del preservativo:

«Después de cada uso, debe lavarse el preservativo con agua y jabón, o simplemente con agua hervida, e inmediatamente después secarlo bien, procurando tenerlo en sitio fresco hasta que haya de usarse nuevamente.

Para su colocación basta enrollarlos, dejando entre la extremidad del pene y el fondo del preservativo un espacio libre de dos o tres centímetros, destinado a recibir la esperma eyaculada».

Por otra parte, al igual que las que existían fuera de España y principalmente en Francia (como el famoso Guide rose), las llamadas Guias nocturnas empezaron entonces a hacer su aparición en las grandes ciudades españolas en los

109 Catálogo especial de preservativos para el uso de ambos sexos, de la casa Hygins and Sanitary Co, antes F. B. Garcés y Cía, Rambla del Centro, núm. 12, pral., Barcelona, para el año 1911, cit. por C. J. CELA, Enciclopedia del erotismo, op. cit., t. I, pp. 106-107 (con reproducciones de varias páginas del catálogo).

110 La Reserva Melquiades Alvarez, 6 Oviedo Sección dedicada exclusivamente a la venta de preservativos (absolutamente irrompibles) contra enfermedades venéreas Catálogo único, Oviedo, Bazar Médico, s.f. [c. $1920], 6$ p. s.p.

111 iiContra el azote de la bumanidad!! iiContra las enfermedades venéreas!! Artículos higiénicos, de verdadera utilidad y eficacia, indispensables en todo bogar moderno, hoja volante, Valencia, Generación Consciente, s.f. [c. 1931]. 
años treinta: Barcelona ${ }^{112}$, Madrid ${ }^{113}$, Valencia ${ }^{114}$, y Zaragoza ${ }^{115}$, por lo menos, contaron con sus respectivas Guías (no las conocemos en cambio para Sevilla o Bilbao, entre otras capitales españolas de importancia).

El amateur o el simple curioso podía encontrar en ellas una relación pormenorizada de los diversos establecimientos locales en donde se practicaba el sexo venal, así como varias publicidades para los necesarios preservativos - las famosas «gomas»- o clínicas venéreas en caso de «incidente» o para mayor seguridad frente a una práctica sexual potencialmente peligrosa.

Durante el primer franquismo, estos tipos de publicidad desaparecieron pero no la venta, de nuevo semi clandestina, y, por lo tanto, el uso de condones. Desde luego, la ley del 24 de enero de 1941 prohibía en su artículo 14 cualquier forma de propaganda anticonceptiva:

«La divulgación pública, en cualquier forma que se realizare, de medios o procedimientos para evitar la procreación, así como todo género de propaganda anticoncepcionista, será castigada con la pena de arresto mayor en su grado mínimo (de un mes y un día a dos meses) y multa de 500 a 5000 pesetas. Será castigada con igual pena la exposición pública y ofrecimiento en venta de objetos destinados a evitar la procreación»116.

El Código Penal de 1944 condenaba igualmente en su artículo 416, dentro del apartado dedicado al aborto, la utilización, la divulgación y la venta de medios destinados a prohibir la procreación:

«Serán castigados con arresto mayor y multa de 1.000 a 25.000 pesetas los que, con relación o medicamentos, sustancias, objetos, instrumentos, aparatos, medios o procedimientos capaces de provocar o facilitar el aborto o de evitar la procreación realicen cualquiera de los actos siguientes:

[...] $4^{\circ} \mathrm{La}$ divulgación en cualquier forma que se realizare de los destinados a evitar la procreación, así como su exposición pública y ofrecimiento en venta»117.

Pese a ello, la venta de preservativos siguió en rastros o puestos de tabaco y chicle, y a partir de los años cincuenta, se podían encontrar en algunas farma-

112 Barcelona de noche. Guía general de Barcelona y particular nocturna con los datos e indicaciones precisos para pasar alegremente el rato en esta bermosa capital (cubierta exterior: Guía Nocturna de Barcelona La Luna), Barcelona, Imp. R. Granados, s.f., 95 p.; Guía Nocturna, s.l. [Barcelona], s.ed., s.f., 10 p.

113 Guía Madrid de noche 1931, Director Antonio Aullón Gallego, Madrid, 1931; Guía Madrid de noche. Año II, tercera edición, Director: Antonio Aullon Gallego, Madrid, 1932, 186 p.

114 Guía Nocturna de Valencia, Valencia, Artes y Letras, 1930, 8 p., cit. por SolAz AlBERT, Rafael: La Valencia probibida, op. cit. Venía en tres idiomas (castellano, inglés y alemán), por lo que se dirigía también a los turistas extranjeros.

115 Guia Nocturna. Zaragoza de noche, Zaragoza, La Tipográfica, 1934, s.p.

116 JIMÉNEZ ASENJO, E.: El anticoncepcionismo ante la moral y la ley penal, op. cit., p. 128.

117 Código Penal Español, Madrid, Instituto Editorial Reus, 1949, p. 108. 
cias, a un precio relativamente alto ${ }^{118}$. Como lo reconocía Jiménez Asenjo, «usar los anticoncepcionales en la intimidad, y sin trascendencia pública, será inmoral por vicio o por pecado, pero no puede ser delito [...]» ${ }^{119}$. Y, según testimonios orales, el condón seguía utilizándose entonces más como preservativo contra las enfermedades venéreas que como medio anticonceptivo ${ }^{120}$.

Parece ser, pues, que de finales del siglo XVIII a la primera mitad del siglo $\mathrm{XX}$, los condones siguen asociados, en general dentro de una relativa clandestinidad, a los ambientes prostitucionales y a las enfermedades venéreas que podían aparecer de tales encuentros sexuales. En todo caso, y salvo excepciones que hemos comentado, la popularización del condón no es entonces obra de los médicos, ni mucho menos de los poderes públicos. Antes bien, desaconsejaban, por lo general, su utilización, más por razones morales que extrictamente médicas, a la diferencia de lo que sucede actualmente en relación con el SIDA. A pesar de todo, venía confirmándose, desde principios del siglo XIX, la función dual del condón, tanto como contraceptivo que como profiláctico.

118 Ver RegueILLET, Anne-Gaëlle: La sexualidad durante el franquismo: discurso pedagógico y realidades cotidianas, Tesis doctoral dirigida por Jean-Louis GuereñA, Tours, Universidad François Rabelais, 2004.

119 JIMÉNEZ ASENJO, E.: El anticoncepcionismo ante la moral y la ley penal, op. cit., p. 21.

120 NieTo, José Antonio: La sexualidad de las personas mayores en España, Madrid, Ministerio de Asuntos Sociales, 1995, p. 239.

Hispania, LXIV/3, núm. 218 (2004) 869-896 